Article

\title{
A Major Ecosystem Shift in Coastal East African Waters during the 1997/98 Super El Niño as Detected Using Remote Sensing Data
}

\author{
Zoe L. Jacobs ${ }^{1, *,+}{ }^{\text {, Fatma Jebri }}{ }^{1,+}{ }^{\oplus}$, Meric Srokosz ${ }^{1}{ }^{\oplus}$, Dionysios E. Raitsos ${ }^{2,3}{ }^{(}$, \\ Stuart C. Painter ${ }^{1}{ }^{\circ}$, Francesco Nencioli ${ }^{3}{ }^{\circ}$, Kennedy Osuka ${ }^{4,5}{ }^{\circ}$, Melita Samoilys ${ }^{4}$, \\ Warwick Sauer ${ }^{6}$, Michael Roberts ${ }^{1,7}$, Sarah F. W. Taylor ${ }^{1}$, Lucy Scott ${ }^{8}$, \\ Hellen Kizenga ${ }^{9}$ and Ekaterina Popova ${ }^{1}$ \\ 1 National Oceanography Centre, Southampton SO14 3ZH, UK; fatma.jebri@noc.ac.uk (F.J.); \\ mas@noc.ac.uk (M.S.); stuart.painter@noc.ac.uk (S.C.P.); Mike.Roberts@mandela.ac.za (M.R.); \\ sarah.taylor@noc.ac.uk (S.F.W.T.); e.popova@noc.ac.uk (E.P.) \\ 2 Department of Biology, National and Kapodistrian University of Athens, 15764 Athens, Greece; \\ draitsos@biol.uoa.gr \\ 3 Plymouth Marine Laboratory, Plymouth PL1 3DH, UK; fnencioli@groupcls.com \\ 4 Coastal Oceans Research and Development-Indian Ocean (CORDIO East Africa), 9 Kibaki Flats, \\ Mombasa P.O. Box 10135-80101, Kenya; kosuka@cordioea.net (K.O.); msamoilys@cordioea.net (M.S.) \\ 5 Department of Environment and Geography, University of York, Heslington, York YO10 5NG, UK \\ 6 Department of Ichthyology and Fisheries Science, Rhodes University, Grahamstown 6140, South Africa; \\ w.sauer@ru.ac.za \\ 7 Nelson Mandela University, Ocean Science and Marine Food Security, Port Elizabeth 6001, South Africa \\ 8 South African Environmental Observation Network, Egagasini Node, Cape Town 8012, South Africa; \\ Lucy.Scott@asclme.org \\ 9 Institute of Marine Sciences, Zanzibar P.O Box 668, Tanzania; hellen.kizenga@uvuvi.go.tz \\ * Correspondence: zoe.jacobs@noc.ac.uk \\ + These authors contributed equally to this work.
}

Received: 14 August 2020; Accepted: 22 September 2020; Published: 23 September 2020

check for updates

\begin{abstract}
Under the impact of natural and anthropogenic climate variability, upwelling systems are known to change their properties leading to associated regime shifts in marine ecosystems. These often impact commercial fisheries and societies dependent on them. In a region where in situ hydrographic and biological marine data are scarce, this study uses a combination of remote sensing and ocean modelling to show how a stable seasonal upwelling off the Kenyan coast shifted into the territorial waters of neighboring Tanzania under the influence of the unique 1997/98 El Niño and positive Indian Ocean Dipole event. The formation of an anticyclonic gyre adjacent to the Kenyan/Tanzanian coast led to a reorganization of the surface currents and caused the southward migration of the Somali-Zanzibar confluence zone and is attributed to anomalous wind stress curl over the central Indian Ocean. This caused the lowest observed chlorophyll-a over the North Kenya banks (Kenya), while it reached its historical maximum off Dar Es Salaam (Tanzanian waters). We demonstrate that this situation is specific to the 1997/98 El Niño when compared with other the super El-Niño events of 1972,73, 1982-83 and 2015-16. Despite the lack of available fishery data in the region, the local ecosystem changes that the shift of this upwelling may have caused are discussed based on the literature. The likely negative impacts on local fish stocks in Kenya, affecting fishers' livelihoods and food security, and the temporary increase in pelagic fishery species' productivity in Tanzania are highlighted. Finally, we discuss how satellite observations may assist fisheries management bodies to anticipate low productivity periods, and mitigate their potentially negative economic impacts.
\end{abstract}


Keywords: upwelling; super El-Niño; ecosystem changes; remote sensing; modelling; western Indian Ocean; ocean currents

\section{Introduction}

Living marine resources of the Western Indian Ocean (WIO) are under an ever-increasing threat from the impacts of climate change and increasing coastal populations [1]. The coastal zones of the WIO represent a pillar for the economic sector and food [2], with a third of the regional population living within $100 \mathrm{~km}$ of the coast [3]. Harvesting living marine resources is a key activity of local populations, especially in Kenya and Tanzania where marine fish provide the major protein intake for coastal inhabitants [4] and often the only source of protein for those with low income [5]. However, existing data show that food insecurity is likely to grow for these East African countries [6], especially with the increased likelihood of poleward redistribution of marine species under the impact of climate change, leading to fisheries transgressing national boundaries [7]. This, combined with unsustainable exploitation of living marine resources [8], could exacerbate resource-use conflicts around key coastal cities for economic activities surrounding fisheries such as Dar es Salaam (Tanzania, Figure 1c) and Mombasa (Kenya, Figure 1c) [8,9].
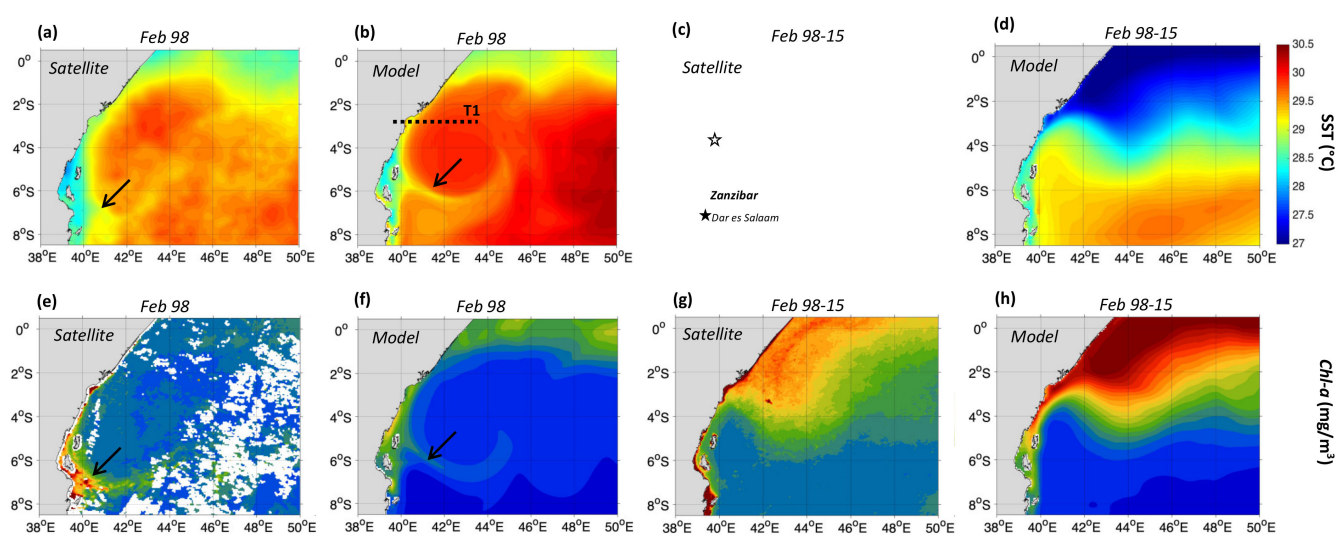

Figure 1. The surface signature of the North Kenya Bank (NKB) upwelling during February 1998, relative to the climatology (1998-2015). SST $\left({ }^{\circ} \mathrm{C}\right)$ in February 1998 from (a) satellite data and (b) the model is shown, relative to $(\mathbf{c}, \mathbf{d})$ their climatological means. Chl-a $\left(\mathrm{mg} / \mathrm{m}^{3}\right)$ in February 1998 from (e) satellite data and (f) the model is shown, relative to $(\mathbf{g}, \mathbf{h})$ their climatological means. The black arrows on (a), (b), (e) and (f) indicate the position of the relatively cool and high Chl-a tongue south of Zanzibar off Dar es Salaam. The dotted horizontal line (T1) displayed on panel (b) indicates the position of a cross-section across the NKB upwelling analyzed in Figure 3.

Ecosystem changes and declining fish populations are important drivers responsible for fisheries conflicts in East Africa [8,10]. Historically, these have respectively caused 25\% and 55\% of the disputes between fishers and governments in Tanzania between 1990 and 2017 [10], and tense competition between a variety of users in Kenya [11]. Worldwide it is acknowledged that changes in coastal upwelling systems, which provide more than $40 \%$ of global fish catch [12], can lead to changes in fish abundance $[13,14]$. In the last few decades, such changes have occurred in many upwelling systems around the globe. One example of fish stocks on the move, causing conflict and hardship, is the small pelagic fishery in South Africa where a regime shift signaled in surface temperatures in 2006 triggered the anchovy biomass to move eastwards from the west coast onto the Agulhas Bank [15]. A similar situation was recorded in eastern Tasmania, where oceanic warming decreased phytoplankton blooms by up to $50 \%$, causing a change in regional fish composition [16]. Another example is that seasonal changes in the Canary Current upwelling system are known to lead to the latitudinal migration of 
small pelagics, spanning the borders of three countries in the eastern North Atlantic [17]. Such changes can lead to significant socio-economic conflicts and even "fish wars" between nations over rich fishing grounds [18]. For instance, the migration of the mackerel stock into northern Atlantic waters [19] triggered an interstate conflict between the European Union, Norway, Iceland and the Faroe Islands over the size and allocation of fishing quotas [20]. Climate change impacts are likely to make similar scenarios more commonplace in all regions of the world ocean, and the East African waters are not an exception.

Large perturbations in atmospheric forcings and the circulation patterns and, consequently, in coastal upwellings are often trigged by climate variability modes such as El Niño-Southern Oscillation (ENSO) [21]. Previous studies have documented the impact of El Niño and/or the Indian Ocean Dipole (IOD) on marine ecosystems in the wider Indian and Pacific Oceans. The widespread warming of up to $2{ }^{\circ} \mathrm{C}$ in the WIO [22] and exceeding $4{ }^{\circ} \mathrm{C}$ in some parts of the eastern Pacific [23] caused major changes in the large-scale distribution of pelagic fish. For example, the reduced nutrient concentrations off the coasts of Peru and Chile during strong El Niño events led to the southward migration of anchovies, sardines and mackerel, which resulted in an anomalously low catch [24-28]. Specifically, in Chile, there was a large, but temporary, reduction in anchovy catch in 1998 (400,000 t), which recovered by 1999 (1,200,000 t $)$ [29]. Despite this, the migration of tropical species, typically found in warmer waters further north, appeared along this coastline, increasing the number of species found in the region $[27,28]$.

There are also changes in the open ocean with an eastward shift of tuna observed in the Pacific Ocean, associated with the eastward shift of the convergence zone [30,31]. This is also observed in the Indian Ocean during strong El Niño and positive IOD events, reducing the catch further west [32-34]. For example, a sudden eastward shift of tuna catches of up to $20^{\circ}$ occurred at the height of the $1997 / 98$ event [35].

Although previous studies have investigated the impact of El Niño and/or the Indian Ocean Dipole (IOD) on marine ecosystems in the wider Indian Ocean, the impact on regional upwelling systems remains only partially documented. In particular, no attempt has yet been made to assess the influence on the ocean circulation and its biological response on the North Kenya Banks (NKBs). This part of the WIO is subject to considerable changes associated with monsoonal variability (see Supplementary Text S1 and Figure S1). The NKBs are also the site of a persistent upwelling cell initiated by the divergent flow of the South Equatorial Counter Current (SECC) away from the coast [21], which provides key support to a large offshore fishery [36]. This upwelling feature is only present during the Northeast monsoon (from December to February) (see Supplementary Figure S2 and Text S1), when the Somali Current (SC) meets the East African Coastal Current (EACC) to form the Somali Zanzibar Confluence Zone (SZCZ) [21]. In their study, Jacobs et al. [21] showed how the location of the SZCZ is fundamental for the presence of upwelling over the NKBs. They also indicated a large southward displacement of the SZCZ during the 1997/98 super El Niño, which coincided with the strongest positive IOD (IOD+) event since records began in 1870 [37]. This co-occurrence of both El Niño and IOD+ caused anomalous warming across the region $[38,39]$ greater than the impact of either phenomenon alone [40], leading to large-scale coral bleaching [41] and reduced productivity [42] over the wider WIO.

The aim of this paper is to investigate the effects the super El Niño and strong IOD+ of 1997/98 had on the productivity along the Kenyan and Tanzanian coasts. There is a lack of sufficient in situ measurements in this region due to economic constraints and insecurity [43]. Thus, marine technologies are used (a combination of ocean remote sensing and modelling) to show how a rearrangement of the surface currents of the WIO shifted an established upwelling system at the East African coast from the territorial waters of one country to that of another.

In addition to the widespread warming of up to $2{ }^{\circ} \mathrm{C}$ in the WIO, we demonstrate that the formation of an anticyclonic gyre adjacent to the Kenyan/Tanzanian coast led to the southward migration of the SZCZ. The latter halted upwelling over the NKBs but initiated a temporary increase 
in productivity just south of Zanzibar Island. This generated the lowest and highest chlorophyll-a (Chl-a, index phytoplankton biomass) concentrations ever recorded in satellite observations at the NKBs and in the vicinity of Dar es Salaam, respectively. The southward migration of the SZCZ in 1997/98 is attributed to the strength and spatial distribution of anomalous Wind Stress Curl (WSC) over the central Indian Ocean, which did not occur during other super El Niño / strong IOD events of 1972/73, 1982/83 and 2015/16.

\section{Materials and Methods}

\subsection{Satellite Observations}

Satellite altimetry-derived products processed by AVISO (Archiving, Validation and Interpretation of Satellite Oceanographic Data) and distributed by the Copernicus Marine Environment Monitoring Service (CMEMS; http://marine.copernicus.eu/services-portfolio/access-to-products/) are exploited in this study.

These are the daily Sea Surface Height Anomalies (SSHA), absolute geostrophic zonal and meridional velocities gridded at $25 \mathrm{~km}$ spatial resolution from the "Update"DUACS-DT2018 (Data Unification and Altimeter Combination System-Delayed Time 2018) version. This gridded geostrophic velocity current field product uses all satellite missions and applies the $\beta$ plane approximation to overcome the geostrophic limitation near the equator (see Pujol et al. [44]). This altimetry product version is generated with a specific reprocessing which holds short spatial scale variations (along-track loess filter with a $40 \mathrm{~km}$ wavelength cutoff) and a high-resolution tidal correction (see Taburet et al. [45]). It is noteworthy that this AVISO product contains long-wavelength error correction which removes correlated noise due to orbit errors or uncertainties in geophysical corrections. Note that AVISO was chosen over GlobCurrent which is an alternative product. Although their comparisons reveal similar features, AVISO has the advantage of being commonly used to validate the NEMO model in many world regions. We compute the climatological monthly means over the period 1993-2015 and monthly means of Eddy Kinetic Energy (EKE), over the same period, following the equation:

$$
\mathrm{EKE}=\frac{1}{2} \sqrt{\mathrm{u}^{2}+v^{2}}
$$

where $\mathrm{u}$ and $v$ are the zonal and meridional components of the surface current, respectively.

Monthly satellite-derived Chl-a concentrations were acquired from the Ocean-Colour Climate-Change Initiative project (OC-CCI; version 3.1; http://www.esa-oceancolour-cci.org/), at a spatial resolution of $4 \mathrm{~km}$. This product is the most consistent time-series of multi-satellite (MODIS-Aqua, SeaWiFS and MERIS) global ocean colour data currently available [46]. Its monthly composites cover September 1997 to June 2018 but only the period that extends until December 2015 is used here to calculate climatological means to be consistent with the model. Note that Chl- $a$ concentrations of February 1998 and 2016 are also examined to investigate potential upwelling events during El-Niño of 1997-98 and 2015-16, respectively.

Another satellite Chl-a dataset considered here is the CZCS Level 3 product [47] provided by Ocean-Color-Web (https://oceancolor.gsfc.nasa.gov/data/czcs/), which covers the 1982-83 super El-Niño period, unlike the CCI Chl-a product. This dataset is available monthly from October 1978 to June 1986 with a local coverage at $4 \mathrm{~km}$ resolution; however, the composites can be sparse due to the cloud coverage, onboard data recording limitations, and the fact that only this single sensor was flying during that period. For the purposes of this study, we only use February 1983 to assess the upwelling signal (due to limited data availability) along the East African coast during the 1982-83 super El-Niño.

The satellite Chl-a observations obtained from both products (CCI and CZCS) may be overestimated near the coast or in shallow optically complex Case II waters, where suspended sediments, particulate matter, and/or dissolved organic matter do not covary in a predictable manner with Chl-a [48]. However, not all the coastal high chlorophyll values are necessarily biases, as some coastal regions have river 
outflows that may be sources of either nutrient or chlorophyll-rich detritus that enhance phytoplankton production near the coast [49]. As the majority of the area included in this study comprises Case-I open waters, this limitation affects only a small proportion of the data (the areas shallower than $30 \mathrm{~m}$ represent a very narrow coastal band). The upwelling cells along the East African coast, which are subject to the influence of El-Niño effects, might have their very coastal points affected by this limitation.

The reprocessed Met Office Operational-Sea-Surface-Temperature-and-Sea-Ice-Analysis (OSTIA) Sea Surface Temperature (SST) product was also acquired. This multi-satellite and global dataset is made available by the CMEMS (http://marine.copernicus.eu/services-portfolio/access-to-products/) from 1985 to 2018. The SST data are provided daily at a spatial resolution of $5 \mathrm{~km}$. We compute monthly means during the study period 1997-2015 to match the observed and modelled Chl- $a$ dataset.

\subsection{Model Configuration and Data}

To examine changes at the subsurface, we utilise a hindcast from a high-resolution, global ocean model, which is coupled to a biogeochemical model. Version 3.6 of the model Nucleus for European Modeling of the Ocean (NEMO) [50] is used, which is configured with a horizontal spatial resolution of $1 / 12^{\circ}$ [21,51]. This corresponds to about $9.25 \mathrm{~km}$ at the equator and has 75 vertical levels with finer grid spacing near the surface, i.e., less than $1 \mathrm{~m}$ at the surface compared to $250 \mathrm{~m}$ at $5500 \mathrm{~m}$ with 22 levels in the upper $100 \mathrm{~m}$. This hindcast spans from 1958 to 2015, with the output stored as 5-day means. The bottom topography is represented as partial steps and bathymetry is derived from ETOPO2 [52]. The Louvain la Neuve (LIM2) sea-ice model is used to represent the sea ice in the global simulation [53]. More information can be found in the online manual here: https://cmc.ipsl.fr/images/publications/scientific_notes/lim3_book.pdf. The various parameterizations are selected by the European consortium with more information found in the NEMO manual here: https://www.nemo-ocean.eu/wp-content/uploads/NEMO_book.pdf.

The run is initialised using the World Ocean Database climatological fields [54] and is forced by the Drakkar Surface Forcing dataset version 5.2, which supplies $2 \mathrm{~m}$ air temperature, $2 \mathrm{~m}$ humidity, $10 \mathrm{~m}$ winds, surface radiative fluxes and precipitation $[55,56]$.

The biogeochemistry is represented by version 2.0 of the Model of Ecosystem Dynamics, nutrient Utilization, Sequestration and Acidification (MEDUSA-2), which is embedded in NEMO, and run from 1990 to 2015 [57]. This is a size-based, intermediate complexity model that divides the plankton community into "small" and "large" components and which resolves the elemental cycles of nitrogen, silicon, and iron. The "small" component of the ecosystem is intended to represent the microbial loop of picophytoplankton and microzooplankton, while the "large" component covers microphytoplankton (specifically diatoms) and mesozooplankton. The non-living particulate detritus pool is similarly split between small, slow-sinking particles that are simulated explicitly, and large, fast-sinking particles that are represented only implicitly. See Yool et al. [56] for a full description of MEDUSA-2.

To be consistent with satellite altimetry data, we consider 1993-2015 as the climatological period for the modelled currents and wind stress. Additionally, the super El Niño periods 1972-1973, 1982-1983, 1997-1998 and 2015 are used for the selected physical (temperature, surface currents, wind stress) parameters while 1997-1998 is the only period included in the MEDUSA-2 timeframe for the biochemical (Chl- $a$, DIN) outputs.

To analyze the mechanisms of circulation changes during super El-Niños (cf. Section 3.3), we investigate the Wind Stress Curl (WSC) forcing over the study. The WSC is calculated, by using the wind stress fields from the model (i.e., the reanalysis dataset used for model forcing) as in the following equation:

$$
W S C=\frac{\partial \tau_{y}}{\partial x}-\frac{\partial \tau_{x}}{\partial y}
$$

where $\tau_{x}$ and $\tau_{y}$ are the zonal and meridional components of the wind stress and $x$ and $y$ are the zonal and meridional dimensions. 
NEMO and MEDUSA-2 have been successfully used to study ocean dynamics in the Indian Ocean $[14,21,58]$ and were recently validated over the East African coast, specifically in analysing the NKBs upwelling [21].

\section{Results}

\subsection{Impact of the $1997 / 98$ El Niño on the Surface Circulation}

Figure 2 compares surface current fields from satellite altimetry and the model at the height of the 1997/98 El-Niño between December 1997 and February 1998, with the climatological means for the period 1993-2015 when both altimetry observations and model results are available. In the climatological fields, the SZCZ is shown to progress southward along the Somali and Kenyan coasts from December to February, when it reaches its southernmost position over the NKBs from 3-4 ${ }^{\circ} S$ and flows eastward as the SECC (Figure 2b,d). However, in February 1998 (Figure 2a,c), the SECC appears $3^{\circ}$ further south than normal $\left(6-7^{\circ} \mathrm{S}\right)$, consistent with Jacobs et al. [21], and is anomalously fast $(0.6-0.8 \mathrm{~m} / \mathrm{s})$ compared with the climatological mean $(0.4-0.5 \mathrm{~m} / \mathrm{s})$. These differences in the magnitude of the current speed result from altimetry resolving only the geostrophic component of the currents [44], unlike the modelled currents, which resolve the total current (i.e., both the geostrophic and ageostrophic components of the circulation). The geostrophic component is influenced by the density field whereas the ageostrophic component is more under the influence of the wind. Despite this, the model shows a clear anticyclonic gyre north of the SECC in agreement with the timing, position, and amplitude of the altimetric fields (Figure 2a,c). Hereafter, we call this gyre the Somali-Zanzibar Gyre (SZG). During the 1997/98 El Niño, the SZG appears closer to the coast, larger and stronger than the climatological eddy that forms on the northeast side of the meandering SECC, centred around $2.8^{\circ} \mathrm{S}-44^{\circ} \mathrm{E}$, during a normal year (Figure 2).
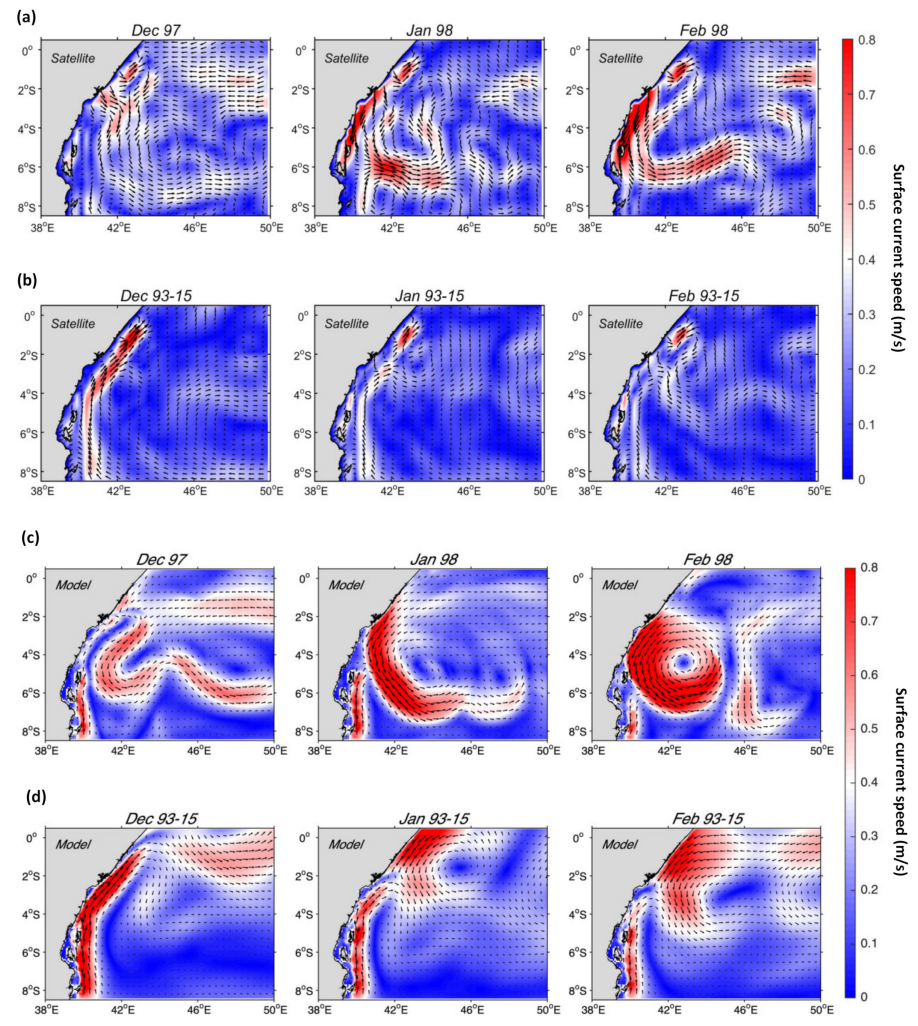

Figure 2. Surface circulation off the East African coast during the 1997-98 El-Niños and Positive Indian Ocean Dipole (IOD+), relatively to the climatology (1993-2015). Surface currents (m/s) between December 1997 to February 1998 from (a) satellite data and (c) the model are presented relative to their (b, d) climatological means. 
The SZG is apparent during all months of the 1997-98 Northeast monsoon. In December 1997, the gyre reaches a maximum horizontal extension of $600 \mathrm{~km}$ and an intensity of up to $0.6 \mathrm{~m} / \mathrm{s}$ (Figure 1a,c). In contrast, the SZG is narrower $(400-500 \mathrm{~km})$ and is more energetic $(0.7-0.8 \mathrm{~m} / \mathrm{s})$ in January and February 1998 (Figure 2a,c). These findings from both the modelled and altimetry-derived currents are in reasonable overall agreement. In both cases (observations and model), January-February remains the period of maximum speed within the SZG, with the SC and EACC making up its western and southern limbs respectively. Therefore, the formation of the SZG is likely blocking the EACC from flowing further north, resulting in an anomalously southward position of the SZCZ and SECC.

\subsection{Collapse of the North Kenya Banks Upwelling}

The southward shift of the SZCZ and the formation of the SZG (Figure 2) have implications for the productivity of the region, as the SZCZ is known to exert a considerable influence on the strength and location of upwelling over the NKBs [21]. This impact is visible in the observed and modelled Sea Surface Temperature (SST) and Chl- $a$ fields, which show a coherent spatial pattern, in February 1998 when the differences are most pronounced (Figure 1). The most noticeable differences compared with the climatological fields are the widespread warming and reduction in Chl- $a$ over the Northwest Indian Ocean (Figure 1a-d), as shown previously in Currie et al. [59]. Additionally, the gyre is visible in the satellite observations as having a warm $\left(>30^{\circ} \mathrm{C}\right)$ and low Chl- $a\left(<0.1 \mathrm{mg} / \mathrm{m}^{3}\right)$ core; while a relatively cool $\left(28.75^{\circ} \mathrm{C}\right.$ ) and high Chl-a (up to $\left.0.6 \mathrm{mg} / \mathrm{m}^{3}\right)$ filamentation is detected at the southern boundary, both of which are well represented in the model (Figure 1a,b,e,f). The region of most intense warming (up to $3{ }^{\circ} \mathrm{C}$ ) compared to the mean (Figure $1 \mathrm{a}-\mathrm{d}$ ) occurs north of $4^{\circ} \mathrm{S}$ from the coast to about $45^{\circ} \mathrm{E}$, which includes the NKBs, and is also associated with the lowest Chl- $a$ concentration (up to $0.4 \mathrm{mg} / \mathrm{m}^{3}$ ) (Figure 1e,f,g,h).

As the model is able to simulate the event at the surface, modelled cross-sections (T1) of temperature, Chl- $a$ and Dissolved Inorganic Nitrogen (DIN) for February 1998, along with their respective anomalies compared to the 1993-2015 climatological mean, were examined to further understand the impact of the SZG on upwelling at the NKBs (Figure 3). Widespread warming seen at the surface (Figure $1 \mathrm{a}, \mathrm{b}$ ) is also apparent at the subsurface with anomalies in excess of $3^{\circ} \mathrm{C}$ down to $100 \mathrm{~m}$ (Figure $3 \mathrm{~d}$ ). This resulted from the deepening of the thermocline and is discussed further in Section 3.
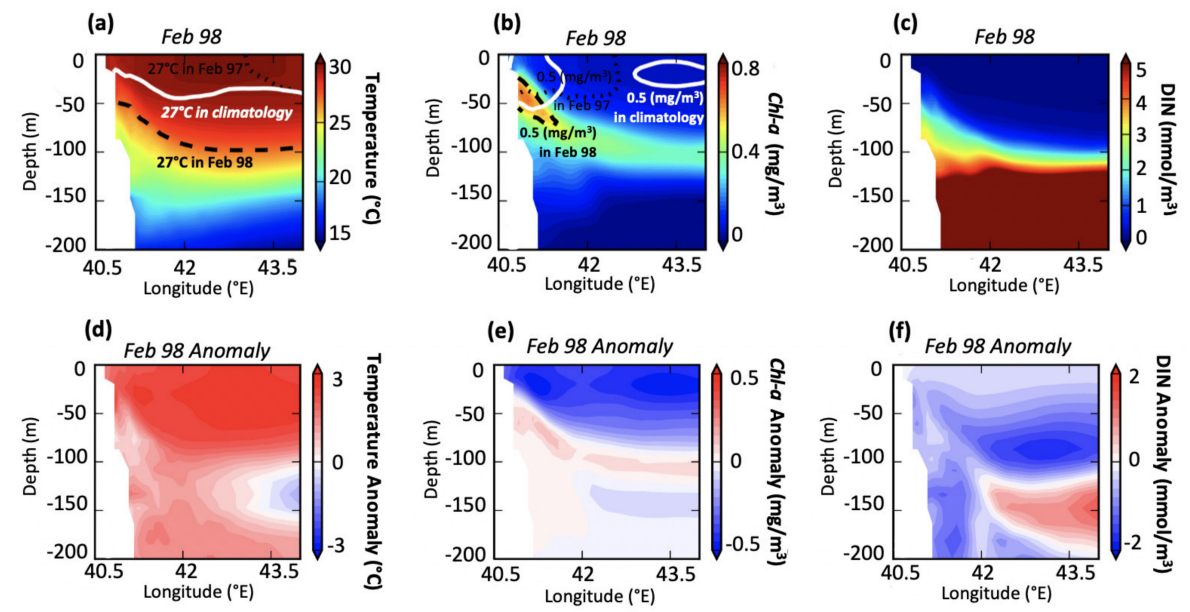

Figure 3. The subsurface signature of the NKB upwelling during February 1998 and its associated anomaly (relatively to 1998-2015 climatological period). Cross-sections of modelled (a) temperature in ${ }^{\circ} \mathrm{C}$, (b) Chl-a in $\mathrm{mg} / \mathrm{m}^{3}$ and (c) DIN in $\mathrm{mmol} / \mathrm{m}^{3}$ and $(\mathbf{d}, \mathbf{e}, \mathbf{f})$ their respective anomalies are displayed along the location $\mathrm{T} 1$ indicated on panel (b) of Figure 2. The dashed black, solid white dotted black and lines on panel (a) represent the $27^{\circ} \mathrm{C}$ isotherm in February 1998, climatological February and February 1997, respectively. The dashed black, solid white dotted black and lines on panel (b) represent the $0.5 \mathrm{mg} / \mathrm{m}^{3}$ isoline in February 1998, climatological February and February 1997, respectively. 
The deepening of the $27^{\circ} \mathrm{C}$ isotherm in February 1998, compared to the mean and to February 1997, indicates a much weaker upwelling (Figure 3d). This is also apparent in the Chl- $a$ and DIN fields with negative anomalies occurring throughout much of the upper $100 \mathrm{~m}$ (Figure 3e,f). The greatest Chl- $a$ concentration occurs at the subsurface from 30 to $60 \mathrm{~m}$ in February 1998, which contrasts with the surface maximum in the climatological mean (contours indicate $0.5 \mathrm{mg} / \mathrm{m}^{3}$ ) (Figure $3 \mathrm{~b}$ ). This, combined with the reduced uplift of nutrients, indicates a clear suppression of upwelling over the NKBs during the 1997-98 El Niño.

In contrast to the collapse of the NKBs upwelling where warm (up to $30^{\circ} \mathrm{C}$ ), unproductive $\left(0.2 \mathrm{mg} / \mathrm{m}^{3}\right)$ conditions exist, a cold $\left(28.75^{\circ} \mathrm{C}\right)$ and productive $\left(>0.6 \mathrm{mg} / \mathrm{m}^{3}\right)$ tongue is observed (and modelled) near the new anomalously southward SZCZ (Figure 1a,c) from $6-7^{\circ} \mathrm{S}$ near southern Zanzibar and Dar es Salaam (Figure 2a,b,e,f). Under the influence of the observed Chl-a, this productive tongue extends from the coast to about $45^{\circ} \mathrm{E}$. During February 1998, the upwelling near the NKBs is halted and a temporary upwelling cell near southern Zanzibar Island and Dar es Salaam is initiated, a situation that lasted for 1-2 months.

\subsection{Key Mechanisms for the Surface Circulation Changes in 1997-98}

Satellite SST, SSHA and EKE fields over the Indian Ocean prior to the onset of and during the 1997-98 Northeast monsoon were examined to better understand the factors that caused the shutdown of upwelling at the NKBs and led to the formation of the SZG.

The WIO experienced broad-scale warming with SST peaking above $32{ }^{\circ} \mathrm{C}$, which is more than $2{ }^{\circ} \mathrm{C}$ warmer than normal (Figure 1). The satellite SST also shows an unusual change in the zonal position of the Southern Equatorial Current (SEC) during December 1997, from a normal westward direction (Figure 1a) to a north-westward flow (Figure 1). The change in the SEC position could lead to large current anomalies [60] and the accumulation of warm waters in the WIO (i.e., higher SST than normal and the Eastern Indian Ocean) is likely generated by increased positive SSHA in the equatorial Indian Ocean [61].

Indeed, the SSHA weekly succession between May 1997 and May 1998 captured by satellite altimetry and the model show exceptionally elevated values $(>30 \mathrm{~cm})$ in the West against decreased values $(<-20 \mathrm{~cm})$ in the East of the Indian Ocean (see Supplementary Videos S1, S2 and Text S2). The anticyclonic SZG is observed in the westward-flowing SEC by September 1997 and a series of anticyclonic eddies forming off southwest India, the Laccadive High (LH) [62], flows southwestward towards the East African coast. Hereafter, we call this flow "Laccadive High/Northeast flow" (LH/NE). The increased variability of the SEC and LH/NE flows is well reflected in the Eddy Kinetic Energy fields (see Supplementary Figure S3 and Text S2). They converge on 22 December 1997 (Figure 4), causing an abrupt separation of the SZG from the main SEC flow and its migration further to the west during late December, where it interacts with the SC and EACC near the Kenyan and Tanzanian coasts. Snapshots of the observed SSHA fields on 22 December 1997 (super El-Niño period) relative to 26 December 2005 (a non-El-Niño period) are illustrated in Figure 4 as they show the convergence of the SEC and LH/NE flows and the detached SZG.

The basin-scale chevron shape ('<') pattern (pointing west) that the currents (LH/NE and SEC) sign in both observed and modelled SSHA (Figure 4a,b) was identified as a basin-wide westward Rossby wave [63]. A time-space diagram along the latitude line $6^{\circ} \mathrm{S}$ of altimetric SSHA shows a westward movement, indicative of Rossby wave propagation [64,65], with the SZG propagating westward from the southeastern Indian Ocean towards the East African coast between November 1997 and March 1998 at a speed of $0.25 \mathrm{~m} / \mathrm{s}$ (Supplementary Figure S4, dashed black circles), which is close to the Rossby wave first mode speed for the region $(0.2 \mathrm{~m} / \mathrm{s}$ [66]). These downwelling Rossby waves depressed the thermocline in the southwestern Indian Ocean in December 1997 [65,67].

Anticyclonic WSC forcing in the Indian Ocean is important for the generation of downwelling Rossby waves during strong El-Niños [68] and the co-occurrence of El-Niño and IOD [69]. The WSC fields over the Indian Ocean from December 1997 (Figure 5c) show predominantly strong positive 
values, ranging between 0.7 to greater than $1.5 \mathrm{~N} / \mathrm{m}^{2}$ per $10^{4} \mathrm{~km}$ in the north $\mathrm{WIO}$, in contrast with the central tropical Indian Ocean, which experiences weak WSC, ranging from 0 to $-0.3 \mathrm{~N} / \mathrm{m}^{2}$ per $10^{4} \mathrm{~km}$. However, the north WIO presents less pronounced positive anomalies (Figure $5 \mathrm{~g}$ ) than those of the central tropical Indian Ocean between $60^{\circ}-100^{\circ} \mathrm{E}$. These strong anomalies, exceeding two standard deviations, are western-ocean intensified, i.e., their amplitude increases from the central towards the far WIO with strong variations from $5-10^{\circ} \mathrm{S}, 65-85^{\circ} \mathrm{E}$ (Figure $5 \mathrm{~g}$ ). This is an indication that the WSC in the central Indian Ocean was anomalously relaxed in December 1997, which is crucial for Rossby wave formation and the sustained warming into February 1998 [67]. Additionally, it strongly supports the idea that the WSC forcing over the central Indian Ocean (i.e., SEC path) during 1997/98 played a major part in generating baroclinic instabilities and forming the SZG within the SEC, which interacted later with the SC and EACC.

(a)

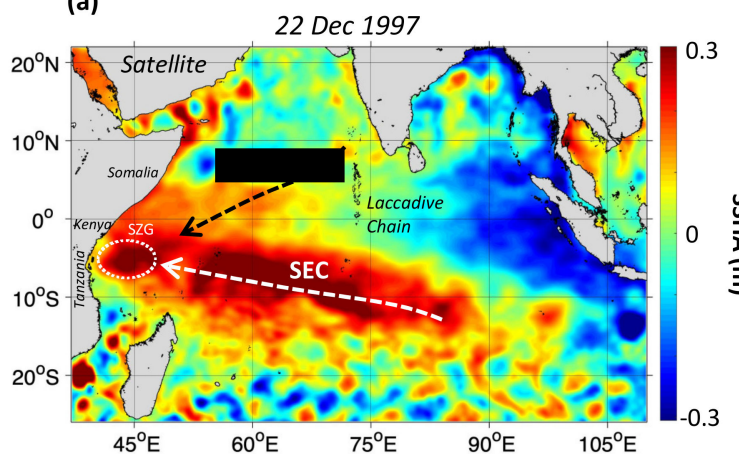

(b)

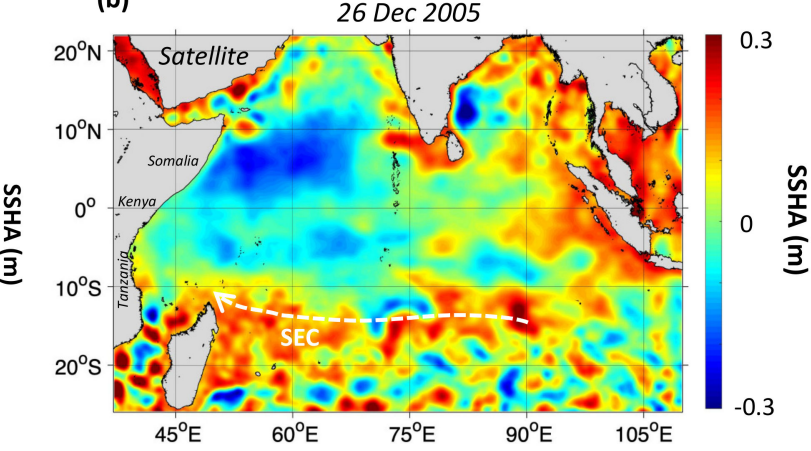

Figure 4. Formation of the Somali-Zanzibar Gyre (SZG) during 1997-98 El Niño and IOD+. Satellite Sea Surface Height Anomalies (SSHA) (m) over the Indian Ocean from (a) on the 22 December 1997 (a super El Niño year) and (b) 26 December 2005 (a non-El-Niño year). A schematic of the convergence of the "Laccadive High/Northeast flow" (LH/NE) and Southern Equatorial Current (SEC) flows is superimposed on panel (a) in dashed black and white arrows and the SZG detaching from the main SEC flow is indicated with a dotted circle.
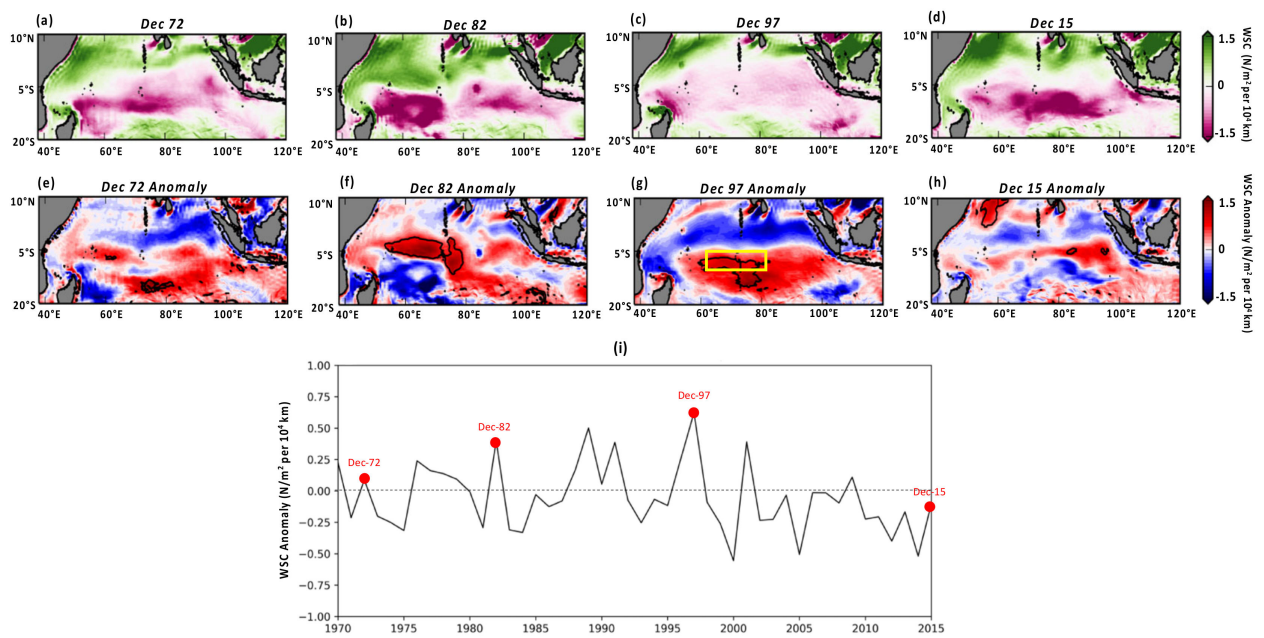

Figure 5. Wind Stress Curl (WSC) forcing over the Indian Ocean during super El Niño and strong IOD events. WSC during Decembers of (a) 1972, (b) 1982, (c) 1997 and (d) 2015 and their (e,f,g,h) associated anomalies (relatively to the period 1993-2015) are shown. The solid black contour lines indicate where anomalies are greater than two standard deviations. (i) Timeseries of the WSC anomalies averaged over the central Indian ocean area delimited by the yellow box shown on panel (g) for all Decembers of 1970-2015. 


\subsection{The NKB Upwelling During Other Super El Niño/Strong IOD Events}

The effects of super El-Niños and strong IODs in 1972/73, 1982/83 and 2015/16 can be evaluated in the available satellite observations and model output. As the model is able to simulate the effects of the 1997/98 event, it can be used to investigate the events that occurred before the satellite observation period began. These showed normal upwelling conditions over the NKBs and an absence of the SZG (Supplementary Figures S5-S7 and Text S3). A strong north-south SST gradient was detected at the confluence zone in February of these years (Supplementary Figure S6), which is a manifestation of normal Northeast monsoon conditions caused by the intrusion of the cold and southward SC meeting the warm and northward-flowing EACC near the NKBs [70].

What was different during 1997/98 in the larger Indian Ocean compared to these other events of similar intensity was the WSC strength and spatial distribution (Figure $5 a, b, d$ ). These years saw moderate to intense negative WSC over the Southern Tropical Indian Ocean, from -0.7 to $-1.5 \mathrm{~N} / \mathrm{m}^{2}$ per $10^{4} \mathrm{~km}$, while December 1997 was near zero to slightly negative (Figure 5c). Their associated positive anomalies are weaker over the central Indian Ocean (Figure $5 \mathrm{e}, \mathrm{f}, \mathrm{h}$ ), indicating significant WSC intensifications, compared with 1997/98 which showed an important WSC relaxation (Figure 5g). On the other hand, WSC anomalies averaged over the central Indian ocean area, as delimited by the yellow box in Figure S6d, during all Decembers of 1970-2015, show that the strongest positive WSC anomaly $\left(0.65 \mathrm{~N} / \mathrm{m}^{2}\right.$ per $\left.10^{4} \mathrm{~km}\right)$ occurred in December 1997 (Figure 5e). In contrast, the positive WSC anomalies of Decembers 1972, 1982 and 2015 over the same area do not exceed $0.35 \mathrm{~N} / \mathrm{m}^{2}$ per $10^{4} \mathrm{~km}$, which is almost half the increase of December 1997 (Figure 5e). Note that WSC in Novembers of the same years and their associated anomalies show similar patterns to those of Decembers (Supplementary Figure S8).

\section{Discussion}

Using a combination of marine technologies, this study investigates the effects of the super El Niño and IOD+ events of 1997/98 on the NKBs upwelling. This approach offers a feasible alternative to in situ measurements, which are still lacking in this region. The novel results found here show how this event led to a unique reorganization of the surface circulation in the WIO, which caused an unprecedented displacement of the NKBs upwelling from Kenyan national waters to south of Zanzibar Island in Tanzanian national waters. Consequently, the reduced nutrients and phytoplankton biomass at the NKBs (Figures 2 and 3) might have had negative impacts on local fish stocks, while the short-lived upwelling cell (Figure 3) that is initiated near Zanzibar may have provided an increase in pelagic fishery species' productivity during this period.

It is difficult to separate the effects of the widespread warming due to El Niño and the temporary "regime swing" of the established upwelling cell away from the NKBs. However, the increase in Chl-a observed at $7^{\circ} \mathrm{S}$ (Figure 2e,f) suggests that the upwelling cell may have led to some temporary relief from the widespread warming and low productivity in Tanzania. For example, Bultel et al. [71] demonstrated that the Tanzanian reconstructed fisheries catch did not decline in 1997-98 for Zanzibar and the mainland as a whole. In contrast, Le Ménache et al. [72] reported a substantial decrease in recreational fish catch by tourists over the NKBs from 17,000 tons in 1990 to around 700 tons during 1997-98. Although the main cause was attributed to a reduction in coastal tourism following political riots [73], Akunga [74] reported from local fishermen surveys that the 1997-98 pelagic fish catch was the worst they had had over a 10-year period. The same study presents catch time-series (for different pelagic species) covering Malindi (in the NKBs) from 1998-2010 and Mombasa (south of the NKBs) from 1996-2010, which show a considerable reduction during 1997-98, before increasing again 1-2 years later. Fulanda et al. [48] also show a sharp decline in catches in Ungwana Bay during this period, which is adjacent to the NKBs. This is further supported by an overall drop of around $36 \%$ in catch rates of five commonly used artisanal gears in Mombasa (handlines, spear, speargun, gillnets and basket traps) between 1995 and 1998 [75], indicating a collapse in small pelagic fisheries, which are close to the bottom of the food chain and are tightly coupled to the dynamics of primary producers. 
Despite these reports of reduced catch during the late 1990s, monthly fish catch data are required to confirm the reduced catch near the NKBs and the temporary boost in catch near Zanzibar in February 1998 to provide further evidence that these results are not due to other factors such as global climate change trends or overexploitation. However, they are not easily accessible. This is mainly due to inconsistent and discontinued records being kept by local offices during this time period, i.e., data only recorded for some months, at different locations and for different species. The catch data recording system in Zanzibar and Tanzania faces many challenges, including the use of handwritten catch records and hard copy storage in the past [76]. This has led to data loss, especially prior to 2010 [77]. Additionally, data recorders were known to lack capacity/knowledge to identify and group fish species in their respective categories, leading to inaccuracies in recording the catches of small pelagics (sardines and anchovies), for example [78,79]. This makes the available historical data uncertain and their use problematic [80,81].

There is no doubt that some changes in fishery catches in other large marine ecosystems are linked to changes in ocean temperature and, even more importantly, productivity [24-28]. Such ecosystem changes can lead to changes in fish composition and cause shifts in the distribution of certain species [15-17]. The most notable effects of El Niño on the fisheries, particularly the pelagic fishery, are changes in the latitudinal and vertical distribution of species, size structure, reproductive processes and an overall decline in landings [80]. These are expected to lead to an increase in fisher migration, a shift in the distribution of target species and associated loss of revenues, further affecting fishers' livelihoods and food security. The East African marine ecosystem is likely no exception, with the present study finding sizeable temperature anomalies associated with a significant reduction in the NKBs upwelling due to the occurrence of a super El-Niño.

In order to prepare national and local governments for the impacts of such climate extremes (El Niño and IOD+) on socio-economic activities (e.g., a shift in fishery stock abundance), a suitable Early Warning System is desirable. Existing systems in the WIO region include a coral bleaching alert that is published annually since 2009 (https://cordioea.net/coral-bleaching/io-coral-bleaching-alert/). A similar Early Warning System specifically for productivity and fisheries catches might have significant utility in the region. The development of such a system can be implemented based on the assessment of whether currents are deviating from their normal circulation patterns in key areas. This can be achieved through satellite remote sensing data, which proved effective in detecting regime shifts $[13,82,83]$. This is cost-effective, especially in the context of the scarcity of in situ measurements in East African waters due to a combination of economic constraints and issues with maritime security [43]. A simple way to do this is to use near real-time altimetry fields, as the circulation changes are regulated by the SEC when it re-orientates itself as a north-westward flow (as opposed to westward) and by the southern displacement of the SECC. The Early Warning System would warn users of the approach of unusual SEC patterns and impending low productivity, leading to potentially lower fish catches. This would help them implement adequate fisheries and social adaptive measures up to three months in advance and mitigate potentially negative economic impacts. In addition to being cost-effective, using such an Early Warning System could help improve the management of marine and coastal resources of East African countries, which support the critical livelihoods of vulnerable coastal populations [84].

Existing climate preparedness platforms at national, provincial/county/district and local levels (such as co-management units, notably beach management units [85], can ensure effective delivery of this Early Warning System information to end-users (e.g., managers) and resource-users (e.g., fishers). Such tools could help not only fisheries management measures, but also social adaptive measures to prevent potential negative socio-economic impacts.

The 1997/98 event may provide a benchmark for assessing how equatorial teleconnections associated with IOD and ENSO may affect the productivity of the East African coast during future similar extreme events. Further work is needed to fully understand the influence of the wind patterns at the basin-scale, as they seem to be the main remote forcing of these interannual oscillations. It is also vital to understand how these regional wind patterns and ocean current variations are projected to 
change in the future. For example, the monsoon winds over the WIO are projected to weaken during the Northeast monsoon but strengthen during the Southeast monsoon [86], which may affect the surface currents in this region and hence, the NKBs upwelling. As for the IOD and El Niño, there are mixed findings at present on how they are likely to respond to future climate change. Cai et al. [87] found evidence to suggest that the frequency of IOD+ has increased from 1950-99. However, this is likely due to natural variations as future projections find that the interannual variability in IOD remains largely unchanged by the end of the 21st century [88]. Additionally, the occurrence of super El Niño events may double in the future, according to Cai et al. [89], which is in stark contrast to other studies who find no conclusive evidence for change due to the complexity of feedback processes, highlighting the need to isolate climate responses to El Niño [90].

In terms of fisheries, some ocean regions are already experiencing temperature and current changes associated with climate change, which are causing shifts in the distribution of pelagic fish [91]. However, the complexity and heterogeneity of the climatic stressors of marine ecosystems, the uncertainty of the whole ecosystem response to these stressors, as well as the response of the individual marine species, make the determination of future climate change impacts on living marine resources a major challenge [92].

\section{Conclusions}

In this paper, the effects of the super El Niño and strong +IOD in 1997/98 on the regional biological productivity (i.e., in terms of Chl- $a$ and DIN) along the East African coasts are unraveled from historical remote sensing observations and modelling outputs. We show that unique anomalies of wind stress curl over the central Indian Ocean have led to a rearrangement of the surface currents in the Western Indian Ocean. Specifically, the formation of an anticyclonic gyre from baroclinic instabilities within the South Equatorial Current, which flows toward the East African coast. We demonstrate that the formation of the anticyclonic gyre led to the southward migration of the SZCZ, which shifted the NKBs upwelling system from the territorial waters of Kenya to those of Tanzania. This generated a temporary increase in productivity just to the south of Zanzibar Island and the lowest phytoplankton biomass ever recorded in satellite observations at the NKBs.

The satellite data and the model show that the unique situation of 1997/98 at the East African coast did not occur during the other super El Niño / strong IOD events of 1972/73, 1982/83 and 2015/16 with an absence of the SZG leading to normal Northeast monsoon conditions at the NKBs. This was attributed to the different patterns of wind stress curl over the Indian Ocean, which did not generate the same type of anomalies as in 1997/98. However, the shifting of the NKBs upwelling further south may be repeated in the coming years, especially under the accelerating effect of climate change. This scenario can be anticipated through the continuous monitoring of changes in the surface currents from the satellite using near-real-time measurements. Thus, preparing for potential scenarios of low productivity, and hence, fisheries, could be made possible in terms of management practices applied by stakeholders.

Supplementary Materials: The following are available online at http://www.mdpi.com/2072-4292/12/19/3127/s1, Figure S1: Schematic view of the main surface circulation features in the WIO during the (a) Northeast and (b) Southeast monsoons, Text S1: WIO circulation and dynamics of the NKB upwelling: A background, Figure S1: NKB upwelling SST $\left({ }^{\circ} \mathrm{C}\right)$ and SSC $\left(\mathrm{mg} / \mathrm{m}^{3}\right)$ signature as derived from (a) satellite observations during February 2003 and (b) the model during Februarys 2007., Text S2: Increased currents variability in the WIO and generation of the SZG in 1997-98., Figure S3: Increased current variability in the Indian Ocean during 1997-98 El-Niño., Figure S4: (a) Time-Space Diagram altimetric SSHA (in cm) over the period May 1997-May 1998 (b) along the $6^{\circ} \mathrm{S}$ latitude line and between 40-60 E., Figure S5: Surface circulation near the East African coasts during the 1972-73, 1982-83 and 2015-2016 El-Niños/IODs. Text S3: Impact of the 1972-73, 1982-83 and 2015-26 El-Niños / IODs on the surface circulation and the upwelling at the NKB., Figure S6: NKB upwelling surface signature during the 1972-73, 1982-83 and 2015-2016 El-Niños/IODs., Figure S7: NKB upwelling sub-surface signature during the 1972-73 and 1982-83 El-Niños/IODs periods., Figure S8: WSC forcing over the Indian Ocean during super El Niño and strong IOD events of 1972-73, 1982-83, 1997-98 and 2015-16. Video S1: SSHA (cm) from the satellite data over the Indian Ocean for May 1997-May 1998. Video S1: SSHA $(\mathrm{cm})$ from the model data over the Indian Ocean for May 1997-May 1998. 
Author Contributions: Z.L.J. and F.J. developed the original idea, produced the key figures and produced description of the results, M.S. (Meric Srokosz), D.E.R., and E.P. contributed to the development of the idea. M.S. (Meric Srokosz), D.E.R., F.N., and E.P. contributed to interpretation of the results. K.O., M.S. (Melita Samoilys), W.S., M.R., S.F.W.T. and L.S. contributed to the descriptions of fisheries and socioeconomics, D.E.R., K.O., M.S. (Melita Samoilys), W.S., S.F.W.T., L.S. and H.K. conducted the search for fisheries data and information. E.P. coordinated the whole study. All authors reviewed the manuscript. All authors have read and agreed to the published version of the manuscript.

Funding: This research was funded by the Global Challenges Research Fund (GCRF) project under NERC grant NE/P021050/1 in the framework of the SOLSTICE-WIO.

Acknowledgments: The authors wish to thank the Copernicus Marine Environment Monitoring Service (marine. copernicus.eu) for providing the altimetry SSHA, the absolute geostrophic currents and daily SST images. We also would like to thank the ESA Ocean Colour CCI project for processing and providing the 1997-2018 Chl-a dataset online at http://www.esa-oceancolour-cci.org/ and the NASA Ocean-Colour-Web for 1983 Chl-a data available online at (https://oceancolor.gsfc.nasa.gov/data/czcs/). We acknowledge the NEMO consortium for the modelling framework used in this study. The model run was performed using the ARCHER UK National Supercomputing with outputs stored at the Centre for Environmental Data Analysis JASMIN servers and can be provided upon request.

Conflicts of Interest: The authors declare no conflict of interest. The funders had no role in the design of the study; in the collection, analyses, or interpretation of data; in the writing of the manuscript, or in the decision to publish the results.

\section{References}

1. UNESCO-IOC. African Oceans and Coasts. In IOC Information Document; Odido, M., Mazzilli, S., Eds.; UNESCO Regional Bureau for Science and Technology: Nairobi, Kenya, 2009; p. 1255.

2. Taylor, S.F.W.; Roberts, M.J.; Milligan, B.; Ncwadi, R. Measurement and implications of marine food security in the Western Indian Ocean: An impending crisis? Food Secur. 2019, 11, 1395-1415. [CrossRef]

3. Obura, D.; Burgener, V.; Owen, S.; Gonzales, A. Reviving the Western Indian Ocean Economy: Actions for a Sustainable Future-Summary; WWF International: Gland, Switzerland, 2017; pp. 1-20.

4. Ochiewo, J. Social and Economic Impacts of Capture Fisheries and Mariculture. In Regional State of the Coast Report: Western Indian Ocean; UNEP, WIOMSA, Eds.; United Nations: Nairobi, Kenya, 2015; pp. 306-316.

5. Jiddawi, N.S.; Öhman, M.C. Marine fisheries in Tanzania. AMBIO A J. Hum. Environ. 2002, 31, 518-528. [CrossRef]

6. McClanahan, T.R.; Allison, E.H.; Cinner, J.E. Managing marine resources for food and human security. In Food Security and Sociopolitical Stability; Barett, C.B., Ed.; Oxford University Press: Oxford, UK, 2013; pp. 142-168.

7. Pinsky, M.L.; Reygondeau, G.; Caddell, R.; Palacios-Abrantes, J.; Spijkers, J.; Cheung, W.W. Preparing ocean governance for species on the move. Science 2018, 360, 1189-1191. [CrossRef] [PubMed]

8. Masalu, D.C. Coastal and marine resource use conflicts and sustainable development in Tanzania. Ocean Coast. Manag. 2000, 43, 475-494. [CrossRef]

9. Breuil, C.; Grima, D. Baseline Report Kenya. In SmartFish Programme of the Indian Ocean Commission; Fisheries Management FAO component: Ebene, Mauritius, 2014; pp. 1-40.

10. Glaser, S.M.; Devlin, C.; Lambert, J.E.; Villegas, C. Fish Wars: The causes and consequences of fisheries conflict in Tanzania. One Earth Future 2018. [CrossRef]

11. Tunje, J.G.; Tole, M.P.; Hoorweg, J.C.; Shauri, H.S.; Munga, C.N. Conflicts in fisheries resource use along the Vipingo-Mida creek stretch of the Kenyan coast: Causes and implications for fisheries management. Int. J. Fish. Aquat. Stud. 2016, 4, 156-161.

12. Fréon, P.; Alheit, J.; Barton, E.D.; Kifani, S.; Marchesiello, P. 9 Modelling, forecasting and scenarios in comparable upwelling ecosystems: California, Canary and Humboldt. Large Mar. Ecosyst. 2006, 14, 185-220.

13. Kassi, J.-B.; Racault, M.-F.; Mobio, B.A.; Platt, T.; Sathyendranath, S.; Raitsos, D.E.; Affian, K. Remotely Sensing the Biophysical Drivers of Sardinella aurita Variability in Ivorian Waters. Remote Sens. 2018, 10, 785. [CrossRef]

14. Jebri, F.; Jacobs, Z.L.; Raitsos, D.E.; Srokosz, M.; Painter, S.C.; Kelly, S.; Roberts, M.J.; Lucy, S.; Taylor, S.F.W.; Palmer, M.; et al. Interannual monsoon wind variability as a key driver of East African small pelagic fisheries. Sci. Rep. 2020, 10, 1-15. [CrossRef] 
15. Roy, C.; Van der Lingen, C.D.; Coetzee, J.C.; Lutjeharms, J.R.E. Abrupt environmental shift associated with changes in the distribution of Cape anchovy Engraulis encrasicolus spawners in the southern Benguela. Afr. J. Mar. Sci. 2007, 29, 309-319. [CrossRef]

16. Thompson, P.A.; Baird, M.E.; Ingleton, T.; Doblin, M.A. Long-term changes in temperate Australian coastal waters: Implications for phytoplankton. Mar. Ecol. Prog. Ser. 2009, 394, 1-19. [CrossRef]

17. Braham, C.B.; Corten, A. Pelagic fish stocks and their response to fisheries and environmental variation in the Canary Current Large Marine Ecosystem. In Oceanographic and Biological Features in the Canary Current Large Marine Ecosystem; Valdés, L., Déniz-González, I., Eds.; IOC-UNESCO: Paris, France, 2015; pp. 197-213.

18. Pomeroy, R.; Parks, J.; Pollnac, R.; Campson, T.; Genio, E.; Marlessy, C.; Holle, E.; Pido, M.; Nissapa, A.; Boromthanarat, S.; et al. Fish wars: Conflict and collaboration in fisheries management in Southeast Asia. Mar. Policy 2007, 31, 645-656. [CrossRef]

19. Pacariz, S.V.; Hátún, H.; Jacobsen, J.A.; Johnson, C.; Eliasen, S.; Rey, F. Nutrient-driven poleward expansion of the Northeast Atlantic mackerel (Scomber scombrus) stock: A new hypothesis. Elem. Sci. Anthr. 2016, 4, 105. [CrossRef]

20. Spijkers, J.; Boonstra, W.J. Environmental change and social conflict: The northeast Atlantic mackerel dispute. Reg. Environ. Chang. 2017, 17, 1835-1851. [CrossRef]

21. Jacobs, Z.L.; Jebri, F.; Raitsos, D.E.; Popova, E.; Srokosz, M.; Painter, S.C.; Nencioli, F.; Roberts, M.; Kamau, J.; Palmer, M.; et al. Shelf-Break Upwelling and Productivity Over the North Kenya Banks: The Importance of Large-Scale Ocean Dynamics. J. Geophys. Res. Oceans 2020, 125, e2019JC015519. [CrossRef]

22. Yu, L.; Rienecker, M.M. Mechanisms for the Indian Ocean warming during the 1997-98 El Nino. Geophys. Res. Lett. 1999, 26, 735-738. [CrossRef]

23. Chavez, F.P.; Strutton, P.G.; Friederich, G.E.; Feely, R.A.; Feldman, G.C.; Foley, D.G.; McPhaden, M.J. Biological and chemical response of the equatorial Pacific Ocean to the 1997-98 El Niño. Science 1999, 286, 2126-2131. [CrossRef]

24. Barber, R.T.; Chavez, F.P. Biological consequences of el nino. Science 1983, 222, 1203-1210. [CrossRef]

25. Barber, R.T.; Chávez, F.P. Ocean variability in relation to living resources during the 1982-83 El Niño. Nature 1986, 319, 279-285. [CrossRef]

26. Bertrand, A.; Segura, M.; Gutiérrez, M.; Vásquez, L. From small-scale habitat loopholes to decadal cycles: A habitat-based hypothesis explaining fluctuation in pelagic fish populations off Peru. Fish Fish. 2004, 5, 296-316. [CrossRef]

27. Sanchez, G.U.A.D.A.L.U.P.E.; Calienes, R.U.T.H.; Zuta, S. The 1997-98 El Niño and its effects on the coastal marine ecosystem off Peru. Rep. Calif. Coop. Ocean. Fish. Investig. 2000, 41, 62-86.

28. Niquen, M.; Bouchon, M. Impact of El Niño events on pelagic fisheries in Peruvian waters. Deep Sea Res. Part II Top. Stud. Oceanogr. 2004, 51, 563-574. [CrossRef]

29. Escribano, R.; Daneri, G.; Farías, L.; Gallardo, V.A.; González, H.E.; Gutiérrez, D.; Lange, C.B.; Morales, C.E.; Pizarro, O.; Ulloa, O.; et al. Biological and chemical consequences of the 1997-1998 El Niño in the Chilean coastal upwelling system: A synthesis. Deep Sea Res. Part II Top. Stud. Oceanogr. 2004, 51, 2389-2411. [CrossRef]

30. Lehodey, P.; Bertignac, M.; Hampton, J.; Lewis, A.; Picaut, J. El Niño Southern Oscillation and tuna in the western Pacific. Nature 1997, 389, 715-718. [CrossRef]

31. Sugimoto, T.; Kimura, S.; Tadokoro, K. Impact of El Niño events and climate regime shift on living resources in the western North Pacific. Prog. Oceanogr. 2001, 49, 113-127. [CrossRef]

32. Lan, K.W.; Evans, K.; Lee, M.A. Effects of climate variability on the distribution and fishing conditions of yellowfin tuna (Thunnus albacares) in the western Indian Ocean. Clim. Chang. 2013, 119, 63-77. [CrossRef]

33. Syamsuddin, M.L.; Saitoh, S.I.; Hirawake, T.; Bachri, S.; Harto, A.B. Effects of El Niño-Southern Oscillation events on catches of bigeye tuna (Thunnus obesus) in the eastern Indian Ocean off Java. Fish. Bull. 2013, 111, 175-188. [CrossRef]

34. Kumar, P.S.; Pillai, G.N.; Manjusha, U. El Nino southern oscillation (ENSO) impact on tuna fisheries in Indian Ocean. SpringerPlus 2014, 3, 591. [CrossRef]

35. Marsac, F.; Le Blanc, J.L. Oceanographic changes during the 1997-1998 El Niño in the Indian Ocean and their impact on the purse seine fishery. In Proceedings of the 1st Session of the IOTC Working Party on Tropical Tunas, Mahe, Seychelles, 1-4 September 1999; pp. 4-8. 
36. Maina, G.W.; Osuka, K. An EAF baseline report for the small and medium pelagic fisheries of Kenya. In Baseline Reports_Preparation of Management Plans for Selected Fisheries in Africa: Ghana, Kenya, Liberia, Mauritius, Mozambique, Nigeria, Seychelles, Sierra Leone and Tanzania; Koranteng, K.A., Vasconcellos, M.C., Satia, B.P., Eds.; FAO EAF-Nansen Project Report No 23; FAO: Rome, Italy, 2014; pp. 22-89.

37. NOAA. 2020. Available online: https://psl.noaa.gov/gcos_wgsp/Timeseries/DMI/ (accessed on 23 September 2020).

38. Saji, N.H.; Goswami, B.N.; Vinayachandran, P.N.; Yamagata, T. A dipole mode in the tropical Indian Ocean. Nature 1999, 401, 360-363. [CrossRef]

39. Webster, P.J.; Moore, A.M.; Loschnigg, J.P.; Leben, R.R. Coupled ocean-atmosphere dynamics in the Indian Ocean during 1997-98. Nature 1999, 401, 356-360. [CrossRef]

40. Meyers, G.; McIntosh, P.; Pigot, L.; Pook, M. The years of El Niño, La Niña, and interactions with the tropical Indian Ocean. J. Clim. 2007, 20, 2872-2880. [CrossRef]

41. Ateweberhan, M.; McClanahan, T.R.; Graham, N.A.J.; Sheppard, C.R.C. Episodic heterogeneous decline and recovery of coral cover in the Indian Ocean. Coral Reefs 2011, 30, 739-752. [CrossRef]

42. Wiggert, J.D.; Vialard, J.; Behrenfield, M.J. Basinwise modification of dynamical and biogeochemical processes by the positive phase of the Indian Ocean Dipole during the SeaWiFS era. In Indian Ocean Biogeochemical Processes and Ecological Variability; Wiggert, J.D., Hood, R.R., Naqvi, S.A., Brink, K.H., Smith, S.L., Eds.; John Wiley \& Sons: Hoboken, NJ, USA, 2009; Volume 185, pp. 385-405.

43. Bendeković, J.; Vuletić, D. Piracy influence on the shipowners and insurance companies. In DAAAM International Scientific Book 2013; DAAAM International Viennna: Wien, Austria, 2013; pp. 711-718. [CrossRef]

44. Pujol, M.I.; Faugère, Y.; Taburet, G.; Dupuy, S.; Pelloquin, C.; Ablain, M.; Picot, N. DUACS DT2014: The new multi-mission altimeter data set reprocessed over 20 years. Ocean Sci. 2016, 12, 1067-1090. [CrossRef]

45. Taburet, G.; Sanchez-Roman, A.; Ballarotta, M.; Pujol, M.I.; Legeais, J.F.; Fournier, F.; Faugere, Y.; Dibarboure, G. DUACS DT2018: 25 years of reprocessed sea level altimetry products. Ocean Sci. 2019, 15, 1207-1224. [CrossRef]

46. IOCCG. Remote sensing of ocean colour in coastal and other optically complex waters. In Reports of the International Ocean Colour Coordinating Group Number 3; Sathyendrannath, S., Ed.; IOCCG: Dartmouth, NS, Canada, 2000; p. 140.

47. NASA Goddard Space Flight Center; Ocean Ecology Laboratory; Ocean Biology Processing Group. Coastal Zone Color Scanner Experiment (CZCS) Chlorophyll Concentration Data; NASA Ocean Biology DAAC: Greenbelt, MD, USA, 2014. [CrossRef]

48. Fulanda, B.; Ohtomi, J.; Mueni, E.; Kimani, E.N. Fishery trends, resource-use and management system in the Ungwana Bay fishery Kenya. Ocean Coast. Manag. 2011, 54, 401-414. [CrossRef]

49. Raitsos, D.E.; Pradhan, Y.; Brewin, R.J.; Stenchikov, G.; Hoteit, I. Remote sensing the phytoplankton seasonal succession of the Red Sea. PLoS ONE 2013, 8, e64909. [CrossRef]

50. Madec, G. ; The NEMO Team. NEMO Ocean Engine. Note du Pole de Modelisation; Institut Pierre-Simon Laplace (IPSL): Guyancourt, France, 2008; Volume 27, pp. 1288-1619.

51. Marzocchi, A.; Hirschi, J.J.M.; Holliday, N.P.; Cunningham, S.A.; Blaker, A.T.; Coward, A.C. The North Atlantic subpolar circulation in an eddy-resolving global ocean model. J. Mar. Syst. 2015, 142, 126-143. [CrossRef]

52. National Geophysical Data Center. 2-Minute Gridded Global Relief Data (ETOPO2v2); National Geophysical Data Center: Boulder, CO, USA, 2006.

53. Timmermann, R.; Goosse, H.; Madec, G.; Fichefet, T.; Ethe, C.; Duliere, V. On the representation of high latitude processes in the ORCA-LIM global coupled sea ice-ocean model. Ocean Model. 2005, 8, 175-201. [CrossRef]

54. Levitus, S.; Conkright, M.; Boyer, T.P.; O’Brian, T.; Antonov, J.; Stephens, C.; Johnson, L.S.D.; Gelfeld, R. World Ocean Database 1998; Technical Report NESDIS 18; NOAA Atlas; NESDIS: Silver Spring, MA, USA, 1998.

55. Brodeau, L.; Barnier, B.; Penduff, T.; Treguier, A.-M.; Gulev, S. An ERA 40 based atmospheric forcing for global ocean circulation models. Ocean Model. 2010, 31, 88-104. [CrossRef]

56. Dussin, R.; Barnier, B.; Brodeau, L.; Molines, J.-M. The Making of Drakkar Forcing Set DFS5; DRAKKAR/MyOcean Report; LGGE: Grenoble, France, 2016. 
57. Yool, A.; Popova, E.E.; Anderson, T.R. MEDUSA-2.0: An intermediate complexity biogeochemical model of the marine carbon cycle for climate change and ocean acidification studies. Geosci. Model. Dev. 2013, 6, 1767-1811. [CrossRef]

58. Srokosz, M.A.; Robinson, J.; McGrain, H.; Popova, E.E.; Yool, A. Could the Madagascar bloom be fertilized by Madagascan iron? J. Geophys. Res. 2015, 120, 5790-5803. [CrossRef]

59. Currie, J.C.; Lengaigne, M.; Vialard, J.; Kaplan, D.; Aumont, O.; Naqvi SW, A.; Maury, O. Indian Ocean Dipole and El Niño/Southern Oscillation impacts on regional chlorophyll anomalies in the Indian Ocean. Biogeosciences 2013, 10, 6677-6698. [CrossRef]

60. Le Traon, P.Y.; Morrow, R. Ocean currents and eddies. In Satellite Altimetry and Earth Sciences: A handbook for Techniues and Applications; Fu, L.L., Cazenave, A., Eds.; Academic Press: San Diego, CA, USA, 2001; Volume 69, pp. 171-210.

61. Krishnan, R.; Ramesh, K.V.; Samala, B.K.; Meyers, G.; Slingo, J.M.; Fennessy, M.J. Indian Ocean-monsoon coupled interactions and impending monsoon droughts. Geophys. Res. Lett. 2006, 33, L08711. [CrossRef]

62. Subrahmanyam, B.; Robinson, I.S. Sea Surface Height Variability in the Indian Ocean from TOPEX/POSEIDON Altimetry and Model Simulations. Mar. Geod. 2000, 23, 167-195.

63. Jury, M.R.; Huang, B. The Rossby wave as a key mechanism of Indian Ocean climate variability. Deep Sea Res. I 2004, 51, 2123-2136. [CrossRef]

64. Chelton, D.B.; Gaube, P.; Schlax, M.G.; Early, J.J.; Samelson, R.M. The influence of nonlinear mesoscale eddies on near-surface oceanic chlorophyll. Science 2011, 334, 328-332. [CrossRef]

65. Chambers, D.P.; Tapley, B.D.; Stewart, R.H. Anomalous warming in the Indian Ocean coincident with El Nino. J. Geophys. Res. Ocean. 1999, 104, 3035-3047. [CrossRef]

66. Johnson, G.C. Deep Signatures of Southern Tropical Indian Ocean Annual Rossby Waves. J. Phys. Oceanogr. 2011, 41, 1958-1964. [CrossRef]

67. Murtugudde, R.; McCreary, J.P., Jr.; Busalacchi, A.J. Oceanic processes associated with anomalous events in the Indian Ocean with relevance to 1997-1998. J. Geophys. Res. Ocean. 2000, 105, 3295-3306. [CrossRef]

68. Xie, S.P.; Annamalai, H.; Schott, F.A.; McCreary, J.P., Jr. Structure and mechanisms of South Indian Ocean climate variability. J. Clim. 2002, 15, 864-878. [CrossRef]

69. Chakravorty, S.; Gnanaseelan, C.; Chowdary, J.S.; Luo, J.J. Relative role of El Niño and IOD forcing on the southern tropical Indian Ocean Rossby waves. J. Geophys. Res. Ocean. 2014, 119, 5105-5122. [CrossRef]

70. Mayorga-Adame, C.; Ted Strub, P.; Batchelder, H.P.; Spitz, Y.H. Characterizing the circulation off the Kenyan-Tanzanian coast using an ocean model. J. Geophys. Res. Ocean. 2016, 121, 1377-1399. [CrossRef]

71. Bultel, E.; Doherty, B.; Herman, A.; Le Manach, F.; Zeller, D. An update of the reconstructed marine fisheries catches of Tanzania with taxonomic breakdown. In Fisheries Catch Reconstructions in the Western Indian Ocean, 1950-2010; Le Manach, F., Pauly, D., Eds.; Fisheries Centre Research Reports, 23; University of British Columbia: Vancouver, BC, Canada, 2015; pp. 151-161.

72. Le Manach, F.; Abunge, C.A.; McClanahan, T.R.; Pauly, D. Tentative reconstruction of Kenya's marine fisheries catch, 1950-2010. In Fisheries Catch Reconstructions in the Western Indian Ocean, 1950-2010; Le Manach, F., Pauly, D., Eds.; Fisheries Centre Research Reports, 23; University of British Columbia: Vancouver, BC, Canada, 2015; pp. 37-51.

73. Obura, D.O. Kenya. Mar. Pollut. Bull. 2001, 42, 1264-1278. [CrossRef]

74. Akunga, B.G. Influence of Climate Variability on Coastal Small-Scale Fishing Communities in Kenya. Ph.D. Thesis, The School of Environmental Studies, Kenyatta University, Kahawa, Kenya, 2015. Available online: https://ir-library.ku.ac.ke/bitstream/handle/123456789/13278/Influence\%20of\%20Climate\% 20Variability....pdf? sequence=1\&isAllowed =y (accessed on 23 September 2020).

75. Samoilys, M.A.; Osuka, K.; Maina, G.W.; Obura, D.O. Artisanal fisheries on Kenya's coral reefs: Decadal trends reveal management needs. Fish. Res. 2017, 186, 177-191. [CrossRef]

76. Kizenga, H. Primary Productivity and Small Pelagic Fish Catches along the Western Coast of Pemba Island. Master's Thesis, University of Dar es Salaam, Ubungo, Tanzania, 2020.

77. Hamidu, U. Assessment of the Marine Artisanal Fisheries in Tanzania Mainland; Ministry of Agriculture, Livestock and Fisheries Development: Dar es Salaam, Tanzania, 2014.

78. URT. Annual Fisheries Statistics Report; Ministry of Agriculture, Livestock and Fisheries Development: Dar es Salaam, Tanzania, 2015; pp. 1-53. 
79. Anderson, J.; Samoilys, M. The small pelagic fisheries of Tanzania. In Case Studies on Climate Change and African Coastal Fisheries: A Vulnerability Analysis and Recommendations for Adaptation Options; Anderson, J., Andrew, T., Eds.; FAO Fisheries and Aquaculture Circular: Rome, Italy, 2016.

80. Sekadende, B.; Scott, L.; Anderson, J.; Aswani, S.; Francis, J.; Jacobs, Z.; Jebri, F.; Jiddawi, N.; Kamukuru, A.T.; Kelly, S.; et al. The small pelagic fishery of the Pemba Channel, Tanzania: What we know and what we need to know for management under climate change. Ocean Coast. Manag. 2020, 197, 105322. [CrossRef]

81. Sherman, K.; Smith, W.; Morse, W.; Berman, M.; Green, J.; Ejsymont, L. Spawning strategies of fishes in relation to circulation, phytoplankton production and pulses in zooplankton off the northeastern United States. Mar. Ecol. Prog. Ser. 1984, 18, 1-19. [CrossRef]

82. Xu, X.; Zhang, Y.; Chen, Q.; Li, N.; Shi, K.; Zhang, Y. Regime shifts in shallow lakes observed by remote sensing and the implications for management. Ecol. Indic. 2020, 113, 106285. [CrossRef]

83. Gokul, E.A.; Raitsos, D.E.; Gittings, J.A.; Alkawri, A.; Hoteit, I. Remotely sensing harmful algal blooms in the Red Sea. PLoS ONE 2019, 14, e0215463. [CrossRef]

84. van der Elst, R.P.; Groeneveld, J.C.; Baloi, A.P.; Marsac, F.; Katonda, K.I.; Ruwa, R.K.; Lane, W.L. Nine nations, one ocean: A benchmark appraisal of the South Western Indian Ocean Fisheries Project (2008-2012). Ocean Coast. Manag. 2009, 52, 258-267. [CrossRef]

85. Kenya Coastal Development Project. Beach Management Unit Needs Assessment Report. In Kenya Coastal Development Project Component 1; Kenya Coastal Development Project: Mombasa, Kenya, 2013; pp. 1-97.

86. McInnes, K.L.; Erwin, T.A.; Bathols, J.M. Global Climate Model projected changes in $10 \mathrm{~m}$ wind speed and direction due to anthropogenic climate change. Atmos. Sci. Lett. 2011, 12, 325-333. [CrossRef]

87. Cai, W.; Sullivan, A.; Cowan, T. Climate change contributes to more frequent consecutive positive Indian Ocean Dipole events. Geophys. Res. Lett. 2009, 36, L23704. [CrossRef]

88. Zheng, X.T.; Xie, S.P.; Du, Y.; Liu, L.; Huang, G.; Liu, Q. Indian Ocean dipole response to global warming in the CMIP5 multimodel ensemble. J. Clim. 2013, 26, 6067-6080. [CrossRef]

89. Cai, W.; Borlace, S.; Lengaigne, M.; Van Rensch, P.; Collins, M.; Vecchi, G.; Timmermann, A.; Santoso, A.; McPhaden, M.J.; Wu, L.; et al. Increasing frequency of extreme El Niño events due to greenhouse warming. Nat. Clim. Chang. 2014, 4, 111-116. [CrossRef]

90. Stevenson, S.L. Significant changes to ENSO strength and impacts in the twenty-first century: Results from CMIP5. Geophys. Res. Lett. 2012, 39, L17703. [CrossRef]

91. Brander, K. Impacts of climate change on fisheries. J. Mar. Syst. 2010, 79, 389-402. [CrossRef]

92. Hobday, A.J.; Evans, K. Detecting climate impacts with oceanic fish and fisheries data. Clim. Chang. 2013, 119, 49-62. [CrossRef]

(C) 2020 by the authors. Licensee MDPI, Basel, Switzerland. This article is an open access article distributed under the terms and conditions of the Creative Commons Attribution (CC BY) license (http://creativecommons.org/licenses/by/4.0/). 